支部だより

\section{3 年度 東北支部賞贈賞報告}

\section{1. 技術研究賞}

東北支部では，1993 年度より東北支部技術研究賞を設け, 産業界, 官界, 学界など, 異なる各界に属する会員の優れた共 同研究に対して，表彰を実施してきております。これは，異分 野の共同研究を促進し, 機械工学 -工業の進展に寄与するとと もに, 東北地方の産業の活性化, ひいては支部活動の活性化を 図ることを目的としたものであります。

支部技術研究賞選考規定に基づき, 選考委員会を結成し, 応 募研究を対象に慎重に審査選考された結果，2003 年度は，下 記の 2 件に決定しました。 2004年 3 月 13 日開催の支部総会の席 上, 青木康芳第 39 期支部長より各研究グループに賞状と楯が 贈呈されました。

(1) 『マルチプローブ型円筒形状測定機の開発』

\begin{tabular}{|c|c|c|c|}
\hline 員 & 遠藤 & 勝幸 & 福島ハイテクプラザ \\
\hline 員 & 高 & 偉 & 東北大学 \\
\hline 員 & 清野 & 慧 & 東北 \\
\hline
\end{tabular}

（2）『機器冷却を目的とした開口部用能動型消音装置の開発』

正 員 柳本 憲作 鶴岡工業高等専門学校

正 員 渡部 誠二 鶴岡工業高等専門学校

正 員 伊藤 孝宏 オリエンタルモーター株式会社

正員高橋 政行 オリエンタルモーター株式会社

\section{2. 独創研究学生賞}

若い学生諸君を通じて支部活動を活性化する目的で, 1996 年度より, 工業高等専門学校, 大学学部, 大学院修士の学生を 対象に, 独創研究学生賞 (「高専・学部の部」および「大学院 修士の部」）を設け，優れた研究を行った学生に対して表彰を 行っております。

「高専 ·学部の部」は, 2004 年 3 月 6 日に開催の東北学生会 第 34 回学生員卒業研究発表講演会において, 応募のあった 15 件の研究を対象に審査され，受賞者に対して，当日，支部長よ り賞状と副賞が贈呈されました。また，「大学院修士の部」は, 2004 年 3 月 13 日開催の支部第 39 期講演会において, 応募研究 18 件に対して審査が行われ, 同日午後開催の支部総会におい て，受賞者に対して，支部長より賞状と副賞が贈呈されまし

た。それぞれの部に拈ける受賞者は，下記の通りです。

(1) 高専・学部の部

a. 『水熱ホットプレス法によるチタンとハイドロキシアパ タイトの接合に及ほす圧力, 反応時間の影響』

$$
\text { 田中雅明東北大学 }
$$

b. 『光センサを用いた微小接触及び微小変形デバイスの開 発』田島 亮. 日本大学

(2) 大学院修士の部

a.『ハイブリッド型微小重力シミュレータを用いた宇宙ロ ボットの衛星捕獲作業模擬実験』

西牧 洋一東北大学

b. 『金属を含むダイヤモンドライクナノコンポジット薄膜 温度センサ』竹野 貴法東北大学

c. 『ふく射要素法を用いた雲領域における三次元ふく射伝熱 の影響』桜井篤東北大学

最後に，各賞の受賞者の皆様に敬意を表しますとともに今後 のますますのご発展を析念いたします，また，東北支部の発展 のために, 今後とも多数の会員各位が技術研究賞ならびに独創 研究学生賞に, 奮ってご応募下さることを期待しております. なお，2003 年度のこれらの賞の応募要領ならびに规定等につ きましては，本誌「支部だより」(2003 年 7 月号，8月号) に記 載されていますので，ご参照下さい。

（東北支部表彰担当幹事 澤田恵介）

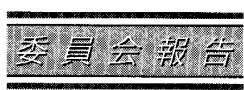

分科会報告 P-SCC2

イメージベースト連成バイオメカニクス解析と その応用に関する研究分科会報告概要*

本分科会は，平成 14 年 4 月にバイオエンジニアリング部門を 申請部門として, 計算力学, 材料力学, 流体工学の 4 部門を横 断して組織され， 2 年間の調査活動を行い，平成 16 年 3 月に終 了した.

計算力学におけるイメージベーストモデリングは，もとも と, バイオメカニクス分野に扔いて必要とされ, 各種の手法が 開発されてきたものであるが，医用画像のために開発されてき た画像取得装置が, 工業目的に応用されるようになって, 新た な展望が開けてきたものである．医用画像は，医用技術が工学 技術をリードし, 発想と開発の原点となっている数少ない技術 分野の一つであり，画像にもとづくモデリングも広い意味でそ の一部と言える。一方, 連成解析は，狭義の流体・固体連成ば かりでなく, 生体を構成する広範な物理・化学現象を連成して 解析しない限り生命の秘密を解き明かし, 有用な技術的応用の 展望を切り開くことができないという意味で, 生命体の科学技 術の根本的な特徵と深く関わっている. さらに，バイオメカニ クスは，単に，工学技術を生体問題に応用するという段階か ら, 生命現象そのものの多物理, 多重スケールの問題を通じ て, 工学技術そのものを考え直すという契機も与えるものであ ることが認識されつつある.

本分科会では, 学界, 産業界から参加者を募り, 最終的に は，44名の委員（主として大学・研究所）および 30 名の企業 オブザーバーによって, 計 6 回の分科会を開催し, 非常に幅広 い関連の話題について, 活発な討論を行うことができた. 本分 科会が目指した研究目標は，まさしく，21 世紀に扔ける統合 的科学技術の基本的, 構造的基盤を見いだし, 確立するという ものであり, 今後, 本分科会に集った我が国でも有数の研究者 集団がこの研究を通じて，世界に誇り得る研究成果を得るもの と信じている.

なお，以上の調查活動を通じて得られた成果は，報告書とし て学会図書館に保管されており，閲覧し，またはコピーサービ ス (有料) を受けることが出来る.

(文責 山口隆美) 